DOI: 10.12731/2070-7568-2017-1-53-63

УДК 327.88

\title{
СИСТЕМНЫЙ КРИЗИС ЗАПАДНОЙ ЦИВИЛИЗАЦИИ В ОСМЫСЛЕНИИ СОВРЕМЕННЫХ РОССИЙСКИХ И ЗАРУБЕЖНЫХ ПОЛИТОЛОГОВ - СРАВНИТЕЛЬНЫЙ АНАЛИЗ
}

\section{Морозов И.Л.}

В статье рассматриваются наиболее характерные кониепиии зарубежных (Дж. Джекобс, С. Хантингтон, П. Бьюкенен, Т. Сарраџин) и российских (А.И. Уткин, А.С. Панарин, И.Н. Панарин) политологов, посвященные выявлению и анализу системных проблем Запада, ведущих его дальнейшее развитие в цүивилизационный тупик, а так же поиску способов схода с негативного тренда развития дальнейших собьтий.

Цель: выявить общее и особенное в зарубежных и российских политико-футурологических концепциях, посвященных осмыслению кризиса современной Западной изивилизации.

Методология исследования: при работе с текстами анализируемых концепций применялся сравнительный метод (компаративный), системный метод.

Результаты исследования: установлена схожесть понимания как зарубежными, так и российскими учеными причинно-следственных связей наблюдаемого кризиса современной Западной ичивилизачии, вылвлены ключевые факторы данного кризиса: отказ от стратегии промышленного производства на собственной территории, утрата «национальной воли» и переход к массовой политической психологической модели толерантности, понимаемой как терпимость и уступчивость требованиям со стороны мигрирующих на Запад народов, массовая психология потребительства (коньсюмеризм), постоянные военные операции стран Запада в различных регионах планеты, ошибочный курс на конфронтацию 
с Россией. Отмечен негативньй тренд политизащии и упрощения при изучении рассматриваемой темы со стороны российских аналитиков, что вызвано конъюнктурой текущего момента.

Область применения результатов: деятельность институтов государственной власти России, ответственньх за принятие и реализацию внешнеполитических решений; академическая разработка новых концепций в теории политики и международных отношений.

Ключевые слова: Запад; кризис; мигранты; война; экономика; Россия; Дж. Джекобс; С. Хантингтон; П. Бьюкенен; Т. Сарраџин; А.И. Уткин; А.С. Панарин; И.Н. Панарин.

\section{THE SYSTEMIC CRISIS OF THE CIVILIZATION OF THE WEST IN UNDERSTANDING OF MODERN RUSSIAN AND FOREIGN SCIENTISTS - COMPARATIVE ANALYSIS}

\section{Morozov I. L.}

This article discusses the most characteristic of the concept of foreign (by J. Jacobs, C. Huntington, P. Buchanan, T. Sarrazin) and Russian (by A.I. Utkin, A.S. Panarin, I.N. Panarin) of political scientists, devoted to the identification and analysis of systemic problems of the West, leading its further development in the civilizational impasse and find ways of gathering the negative trend of further developments.

Purpose: to reveal General and specific features in Russian and foreign political and futurological concepts, dedicated to understanding the crisis of modern Western civilization.

Research methodology: when working with the texts analyzed was used the comparative method, system method.

The results of the study: the similarity of understanding of both foreign and Russian scientists causality of the observed crisis of modern Western civilization, identified the key factors of the crisis: the rejection of the strategy of industrial production on its own territory, the loss 
of "national will" and the transition to a mass political psychological model of tolerance, understood as tolerance and compliance requirements by migrating to the West of the peoples, the mass psychology of consumerism, constant military operations in the Western countries in different regions of the world, the erroneous policy of confrontation with Russia. The negative trend of politicization and simplification in the study of the topic by Russian analysts, caused by market conditions of the moment.

The scope of the results: the activity of institutions of the Russian state authorities responsible for the adoption and implementation of foreign policy decisions; the academic development of new concepts in the theory of politics and international relations.

Keywords: West; crisis workers; war; economy; Russia; J. Jacobs; C. Huntington; P. Buchanan; T. Sarrazin; A. Utkin; A. Panarin; I. Panarin.

Глобализация как вектор развития человеческой цивилизации на современном этапе в вестернизированном варианте концептуально представлялась западным футурологам безальтернативным трендом до начала XXI века. Однако затем ее последствия становились все более очевидными, чтобы их можно было игнорировать. Предпринимается целый ряд попыток осмысления будущего Западной цивилизации, вскрытия негативных трендов, в том числе и тех, обсуждение которых в публичном пространстве замалчивалось по причинам политкорректности. Если Дж. Джекобс, предупреждавшая о грядущей деградации западной культуры и погружения в «новое средневековье» [4], еще испытала на себе попытки изоляции от академического сообщества, то концепцию С. Хантингтона о развале глобального мира на конкурирующие по религиозному признаку цивилизации, уже обсуждали во всех университетах планеты.

Дж. Джекобс, получившая известность благодаря более ранним критическим исследованиям американской урбанистики, выделила следующие «точки уязвимости» социума западных стран: ослабле- 
ние и в будущем массовый распад семей, формализация образования (дипломы становятся общедоступными и их получение не требует таких усилий, как ранее, что негативно сказывается на уровне подготовки специалистов), деградация науки (падение интенсивности достижения новых научных открытий), несправедливость налоговой системы, социально-культурное вырождение городского населения [4, с. 10-93].

Концепция американского профессора С. Хантингтона о грядущем столкновении цивилизаций [11] достаточно подробно изучена в российской политической науке, поэтому отметим только тезис, выражающий беспокойство автора концепции тем обстоятельством, что западная цивилизация пребывает в состоянии разобщенности и кризиса идентичности. Это касается как Запада в целом, так и непосредственно США. Однако на помощь Западу, по мнению С. Хантингтона, невольно пришли агрессивные силы Востока. Начав против США террористическую войну, они перезапустили угасший было процесс укрепления американской национальной идентичности: «Трагические обстоятельства 11 сентября 2001 года вернули Америке ее идентичность. До тех пор, пока американцы считают, что их стране угрожает опасность, национальная идентичность остается весьма высокой. Если же чувство опасности притупляется, прочие идентичности вновь берут верх над идентичностью национальной» [12, с. 15-16].

Характерными представителями крайней, «алармистской» позиции являются американский публицист-политик П. Бьюкенен [2; 3] и германский публицист Т. Саррацин [9]. Работы авторов по ключевым выводам и рекомендациям концептуально схожи даже в деталях, хотя писались, соответственно, на эмпирических данных по США и Германии. Авторы схожи во мнении, что Запад как цивилизационная категория сейчас перестает быть Западом. Хотя Запад и выдержал историческую конкуренцию с внешними соперниками, установил мировую гегемонию, но может пасть под воздействием собственных ошибок и негативных тенденций: открытость для миграционных потоков, размывание религиозно-этической основы 
«белого человека», стремление к паразитарному стилю жизни (избегать работы, получать пособия и налоговые льготы). При этом внутреннее «размягчение» воли западного социума сочетается с агрессивной внешней политикой, что множит врагов и отталкивает потенциальных друзей. П. Бьюкенен прямо указывает на ошибки США, превратившие постсоветскую Россию из союзника и подражателя Америки в опасного военного конкурента [3, с. 559-566]. Ситуация видится в возвращении к традиционализму в культуре, возврату к системе «наций-государств» вместо «глобального мира» на мировой арене. Международная обстановка, оцененная П. Бьюкененом как нестабильная, стала стремительно усложняться под воздействием российско-украинского конфликта с 2014 года и по наши дни [11, с. 18-19].

Обратимся подробнее к российским концепциям, объединяемым условной тематикой «смерти Запада» и рассмотрим три из них, как наиболее характерных: работы А.И. Уткина, А.С. Панарина и И.Н. Панарина.

Доктор исторических наук, профессор А.И. Уткин, возглавлявший при жизни Центр международных исследований Института США и Канады РАН, являлся известным российским специалистом по истории и современности американской внешней политики. В одной из его последних фундаментальных работ [10] предпринята попытка теоретического осмысления будущего Западной цивилизации. Доминирование Запада на планете ослабло в результате двух факторов - внутренние конфликты (Первую и Вторую мировые войны А.И. Уткин трактует как гражданские войны западной цивилизации $[10$, с. 726]) и агрессивная внешняя политика в отношении незападных стран. В итоге политический авторитет США к началу XXI века упал до критического уровня, а успехи индустриализации (и, парадокс, вестернизации) превратили крупнейшие из незападных стран в мощнейшие центры мирового производства - Индия, Китай, Бразилия. Важнейшую роль в падении западной мировой гегемонии сыграет Россия, которая при президенте В.В. Путине отказалась от следования в фарватере американской политики, при- 
ступила к возрождению своей духовности на основе патриотизма и религии, нормализовала отношения с Китаем и модернизировала свой военно-технический потенциал [10, с. 729-730].

Концепция А.И. Уткина отличалась системностью восприятия проблемы, фундированностью историческими данными и актуальными мегатрендами глобального развития и в силу своего академизма осталась в статусе научной теории, не получившей практического применения.

Второй из рассматриваемых российских концепций является интеллектуальное наследие доктора философских наук, профессора А.С. Панарина [5; 6]. Современная западная цивилизация в его работах характеризовалась как предавшая позитивные идеи Просвещения и превратившаяся в международного агрессора-разбойника: «Для того, чтобы Запад мог отодвигать от себя пределы роста, расширяя ресурсную базу своей технической и потребительской цивилизации, нужно, чтобы другие страны и цивилизации открыли для него все свои ресурсы. Отсюда - концепция глобально «открытого общества» и «открытой экономики»»» [6, с. 24]. Реализуя данный подход, Запад приступил к демонтажу (сперва концептуальному, а затем и физическому) национальных государств, насаждая режим проницаемости границ и подавления национального самосознания народов. При этом Запад вводит принцип «двойного стандарта», оставляя за собой право на защиту своих собственных экономических и геополитических интересов, но жестко пресекая аналогичные попытки со стороны иных акторов международной системы.

Итогом такой политики станет отнюдь не формирование глобального гармоничного мира без войн и социальных потрясений, но непредсказуемый, нестабильный и полный опасностей мир. Как отмечает автор: «Стратегическая нестабильность... уже стала судьбой XXI века» [5, с. 11]. Рассматривая всю планету как своеобразный «трофей», доставшийся по итогам победы в «холодной войне», США множат число своих врагов и конкурентов, основными из которых А.С. Панарин назвал Россию, Китай и Индию. Укрепив свою цивилизационную идентичность (Россия - на основе возвра- 
щения к православной духовности), эти новые центры силы неизбежно бросят вызов Соединенным Штатам Америки и превзойдут их. Несмотря на свое внешнее величие, Америка обладает рядом цивилизационных пороков, каждый из которых будет развиваться в будущем и в итоге приведет к ослаблению и краху:

- отказ от реальной производящей экономики и переход к информационной экономике «услуг», что ставит США в зависимость от «мастерских мира», прежде всего Китая и Индии;

- идеология «общества потребления», уничтожающая уважение к труду и разумной самоограниченности в потреблении товаров и услуг;

- торможение научно-технического прогресса, неспособность генерировать новые технологии.

Последнее особенно показательно, так как именно Запад на всем предшествующем периоде эволюции человеческой цивилизации воплощал в себе идею научно-технического прогресса. Однако сейчас, по мнению ряда ученых, ситуация меняется. Как отмечал профессор И.Е. Бельских: «Поиск новых высокотехнологических идей, новаторских решений был присущ человечеству всегда. Исторический процесс показывает, что почему-то одни страны превращаются в передовиков высокотехнологических инноваций (а таких стран единицы), а другие (их подавляющее большинство) остаются всегда на задворках научно-технического прогресса)» [1, с. 40].

В итоге в данной концепции США рассматривается как опасный и сильный противник, однако не лишенный недостатков и обреченный на историческое поражение в силу неправильно выбранной стратегии глобальной политики в XXI веке. Обновленная, избавившаяся от «западного либерализма» и вернувшаяся к своей духовности Россия сыграет в этом процессе ключевую роль.

Третьей из рассматриваемых в данной статье российских теорий, является концепция доктора политических наук И.Н. Панарина $[7 ; 8]$, которая впервые была озвучена автором в 1998 году и предсказывала распад США к 2010 году по следующим причинам: 
- финансовая (рост государственного долга, что неизменно завершится крахом доллара как мировой валюты);

- политическая (большая степень правовой автономии штатов в рамках федерации, выражающаяся в расхождении законодательства);

- этническая (коренные народности требуют независимости);

- геоэкономическая (более богатые штаты, например, Техас, хотят сбросить налоговое федеральное бремя и перестать содержать бедные штаты, к которым автор концепции относит, например, Калифорнию).

И.Н. Панарин предполагал распад США на шесть частей: Аляска, Гавайи, Тихоокеанское побережье, Атлантическое побережье, Техасская республика, Северные штаты (ориентирующиеся на Канаду). Президент США Барак Обама (2009-2017 гг.) трактовался И.Н. Панариным как «американский Горбачев», который не способен управлять страной и доведет США до распада к 2010 году. После распада США в мире будет три глобальных центра силы: Китай (объединившийся с Тайванем), Европейский Союз, Россия (установившая доминирование в Евразии). Совместно эти три центра силы должны стабилизировать обстановку на территории распавшихся США и ввести интернациональные миротворческие войска для спасения уцелевшего населения.

В последующем концепция И.Н. Панарина модифицировалась и дополнялась (например, постоянно сдвигалась в будущее предполагаемая дата распада США) и превратилась в пропагандистскую идеологему, активно продвигаемую российскими СМИ и социальными сетями, нашедшую популярность склонных к конспирологическому восприятию истории и политики патриотически настроенных россиян.

\section{Выводы}

1. Понимание мирового тренда на постепенную девальвацию статуса Западного мира как экономического, культурного, военного центра человеческой цивилизации характерно как для россий- 
ских, так и для зарубежных футурологов. Поиск схода с трека негативного сценария видится в обращении к консерватизму, изоляционизму, национализму.

2. Как западные, так и российские концепции по исследуемому вопросу отличаются политизацией, субъективностью, однако в российских публикациях это выражено более характерно. Кроме того, можно выделить характерную для российской футурологической мысли тенденцию на постепенное упрощение подхода к исследуемому феномену, торжество публицистики над научным анализом. Этому способствовала политическая конъюнктура, сложившаяся в России, а так же обострение противостояния с Западом после исторического воссоединения России с Крымом в 2014 году.

3. Тенденция «размывания» научного политологического знания в России в угоду политической конъюнктуре и его перерождения в сторону публицистики не может быть оценена как положительная и чревата негативными последствиями, в том числе дезориентацией органов государственной власти России, ответственных за принятие внешнеполитических решений.

4. Выявленные в рассмотренных концепциях негативные цивилизационные тренды, угрожающие перейти в системные проблемы, характерны не только для стран Запада, но в определенной степени и для современной России, представляющей собой органичную часть европейского культурного пространства, базирующегося на христианской традиции. Поэтому актуальным становится проведение совместных исследовательских проектов по поиску выхода из цивилизационного тупика «глобализации».

\section{Список литературы}

1. Бельских И.Е. Инновации и альтернативы в современной экономике // Экономика: теория и практика. 2015. № 1 (37). С. 39-43.

2. Бьюкенен П. Смерть Запада. М.: Издательство АСТ, 2003. 444 с.

3. Бьюкенен П. Самоубийство сверхдержавы. М.: Издательство АСТ, 2016. $640 \mathrm{c}$. 
4. Джекобс Д. Закат Америки. Впереди средневековье. М.: Издательство «Европа», 2006. 264 с.

5. Панарин А. С. Стратегическая нестабильность в XXI веке. М.: Издательство Эксмо, Издательство Алгоритм, 2004. 640 с.

6. Панарин А.С. Православная цивилизация в глобальном мире. М.: Издательство Эксмо, 2003. 544 с.

7. Панарин И.Н. Русский Крым и развал США. М.: Издательство Горячая линия-Телеком, 2015. $238 \mathrm{c.}$

8. Панарин И.Н. Крах доллара и распад США. М.: Издательство Горячая линия-Телеком, 2009. 256 с.

9. Саррацин Т. Германия: самоликвидация. М.: Издательство АСТ, 2016. $560 \mathrm{c}$.

10. Уткин А.И. Подъем и падение Запада. М.: Издательство АСТ, 2008. $761 \mathrm{c}$.

11. Хантингтон С. Столкновение цивилизаций. М.: Издательство АСТ, $2005.603 \mathrm{c}$.

12. Хантингтон С. Кто мы? Вызовы американской национальной идентичности. М.: Издательство АСТ, 2004. 635 с.

13. Харыбин А. Н. Современные геополитические конфликты // Общество: политика, экономика, право. 2015. № 1. С. 18-19.

\section{References}

1. Bel'skikh I. E. Innovatsii i al'ternativy v sovremennoy ekonomike [Innovations and alternatives in the modern economy]. Ekonomika: teoriya i praktika. 2015. № 1 (37), pp. 39-43.

2. B'yukenen P. Smert'Zapada. [The Death of the West]. M.: Izdatel'stvo AST, 2003. 444 p.

3. B'yukenen P. Samoubiystvo sverkhderzhavy [Suicide of a superpower]. M.: Izdatel'stvo AST, 2016. 640 p.

4. Dzhekobs D. Zakat Ameriki. Vperedi srednevekov'e [The Decline Of America. Ahead of the middle ages]. M.: Izdatel'stvo «Evropa», 2006. $264 \mathrm{p}$.

5. Panarin A. S. Strategicheskaya nestabil'nost'v XXI veke [Strategic instability in the XXI century]. M.: Izdatel'stvo Eksmo, Izdatel'stvo Algoritm, 2004. $640 \mathrm{p}$. 
6. Panarin A.S. Pravoslavnaya tsivilizatsiya v global'nom mire [The Orthodox civilization in the global world]. M.: Izdatel'stvo Eksmo, 2003. 544 p.

7. Panarin I.N. Russkiy Krym i razval SShA [Russian of Crimea and the collapse of the US]. M.: Izdatel'stvo Goryachaya liniya-Telekom, 2015. 238 p.

8. Panarin I. N. Krakh dollara i raspad SShA [The collapse of the dollar and the collapse of the US]. M.: Izdatel'stvo Goryachaya liniya-Telekom, 2009. 256 p.

9. Sarratsin T. Germaniya: samolikvidatsiya [Germany: self-destruction]. M.: Izdatel'stvo AST, 2016. 560 p.

10. Utkin A. I. Pod"em i padenie Zapada [The rise and fall of the West]. M.: Izdatel'stvo AST, 2008. 761 p.

11. Khantington S. Stolknovenie tsivilizatsiy [The Clash of Civilizations]. M.: Izdatel'stvo AST, 2005. 603 p.

12. Khantington S. Kto my? Vyzovy amerikanskoy natsional'noy identichnosti [Who are We? The Challenges to America's National Identity]. M.: Izdatel'stvo AST, 2004. 635 p.

13. Kharybin A. N. Sovremennye geopoliticheskie konflikty [The current geopolitical conflicts]. Obshchestvo: politika, ekonomika, pravo. 2015. № 1, pp. 18-19.

\section{ДАННЫЕ ОБ АВТОРЕ}

Морозов Илья Леонидович, доктор политических наук, доцент

Волгоградский институт управления ФГБОУ ВО «Российская академия народного хозяйства и государственной службы при Президенте Российской Федерации» ул. Гагарина 8, г. Волгоград, 400131, Российская Федерация politkon@mail.ru

\section{DATA ABOUT THE AUTHOR}

Morozov Ilya Leonidovich, Doctor of Political Sciences, Associate Professor

Volgograd Institute of Management of the Russian Presidential Academy of National Economy and Public Administration 8, Gagarin Str., Volgograd, 400131, Russian Federation politkon@mail.ru 